\title{
Description of a new species of the genus Fonscolombia Lichtenstein (Hemiptera: Coccoidea: Pseudococcidae) from Turkey
}

\section{Türkiye'den Fonscolombia Lichtenstein cinsine ait yeni bir türün tanıtımı (Hemiptera: Coccoidea: Pseudococcidae)}

\author{
M. Bora KAYDAN ${ }^{1 *}$
}

\begin{abstract}
Summary
A new mealybug species, Foncolombia ulusoyi sp. n. (Hemiptera: Pseudococcidae), is described and illustrated based on the adult female. The new species was collected off Stipa sp. and Festuca sp. (Poaceae) at lğdır in Turkey.
\end{abstract}

Keywords: Pseudococcidae, reduced cerarii number, Fonscolombia, Euripersia

\section{Özet}

Çalışmada Iğdır'dan Stipa sp. ve Festuca sp. (Poaceae) üzerinden toplanan yeni tür Foncolombia ulusoyi sp. n. ergin dişi özelliklerine göre tanımlanmıştır.

Anahtar sözcükler: Pseudococcidae, azalmış cerarii, Fonscolombia, Euripersia

\footnotetext{
${ }^{1}$ Çukurova University, Imamoglu Vocational School, Adana, Turkey 


\section{Introduction}

Pseudococcidae family (Sternorrhyncha: Hemiptera: Coccoidea) is the second largest scale insect family worldwide, with over 2018 species in 270 genera (Ben-Dov et al., 2014). In the Palaearctic region 700 species in 106 genera are known (Kozár, 1998). Mealybugs are characterized by the white mealy or powdery wax that covers the soft body of these insects Within the Phenacoccinae subfamily, the genus Fonscolombia Lichtenstein is characterized in having; (i) 6-8 segmented antennae; (ii) well-developed legs; (iii) claw with or without denticle; (iv) quinquelocular pores present or absent on venter and (v) reduced cerarii number (1-6) in posterior abdominal segments (Ben-Dov \& Matile-Ferrero, 1989; Danzig, 2007). Ben-Dov \& Matile-Ferrero (1989) found that the nominal type species, Coccus radicumgraminis Fonscolombe, was a misidentification by Lichtenstein of Fonscolombia graminis Lichtenstein (1877). It is now established that Fonscolombia graminis Lichtenstein is the type species and the genus Fonscolombia Lichtenstein is the accepted name (ICZN, 1991).

The similarities between the genera Fonscolombia and Euripersia (Borchsenius) were discussed by Ben-Dov \& Matile-Ferrero, (1989). Euripersia tomlinii (Newstead) and E. europaea (Newstead) were moved to the genus Fonscolombia by Danzig (1994) and Matile-Ferrero (2004). Danzig (2007) stated that Euripersia is a junior synonym of Fonscolombia, however the worldwide database ScaleNet (Ben-Dov at al. 2014) regards these two genera separately (Euripersia with 8 species, namely Euripersia artemisiae (Hall), E. cribrata cribrata (Menozzi), E. cribrata massiliensis (Goux), E. inquilina (Leonardi), E. libera (Leonardi), E. pennisetus (Tang), E. sardiniae (Leonardi) and E. silvestrii (Leonardi); while Fonscolombia has 10 species namely; Fonscolombia amnicola (Borchsenius), F. butorinae Danzig \& Gavrilov, F. edentata (Danzig), F. europaea (Newstead), F. graminis Lichtenstein, F. herbacea (Danzig), F. stepposa (Matesova), F. stipae (Nurmamatov), F. tomlinii (Newstead) and F. tshadaevae (Danzig).

In Turkey there are 103 mealybug species to date and two Fonscolombia species were recorded namely $F$. europaea and F. amnicola (Kaydan et al., 2013). Here a new species that belongs to the Fonscolombia genus is described and a new key for Fonscolombia species is provided.

\section{Materials and Methods}

Scale insect samples were collected in Erzurum and Iğdır in Turkey between 2008 and 2010. Specimens were taken from both wild and cultivated plants twice a week during the spring and summer seasons. Collecting data, province, locality, GIS coordinates, date of collection, collector, data on the phenological stages of the host plant and KPCT (Coccoidea Collection, in Çukurova University, Adana, Turkey) collection numbers are provided for each collected specimen.

Each sample was placed in a plastic bag and taken to the laboratory for examination. Specimens were slide-mounted for light microscopy using the method of Kosztarab \& Kozár (1988). Morphological terminology follows that of Danzig (2007) and Williams (2004) for new mealybug species description. Measurements and counts of the new species were taken from all available material (see material examined), i.e., holotype and all paratype specimens.

Both dry and mounted non-type material are deposited in the Scale Insect Collection in Çukurova University, Adana, Turkey (KPCT); the holotype and one paratype of the new species are deposited in the Scale Insect Collection in Çukurova University, Adana, Turkey (KPCT). 


\section{Results and Discussion}

\section{Systematics}

\section{Genus Fonscolombia Lichtenstein}

Fonscolombia Lichtenstein, 1877: 35.

Type species: Fonscolombia graminis Lichtenstein, 1877 designated by International Commission of Zoological Nomenclature (ICZN, 1991).

Euripersia Borchsenius, 1948: 956. Type species Euripersia amnicola Borchsenius, 1948 by original designation.

Conicoccus Goux, 1994: 41. Type species: Conicoccus montrottieri Goux, by original designation. Synonymy by Matile-Ferrero, 2004: 74 .

\section{Diagnosis}

\section{Living female.}

Female covered with white powdery wax. Ovisac woolly, white. Generally found on the roots of the host plant.

\section{Adult female.}

Antennae 6-8 segmented (in $F$. edentata and $F$. herbacea 7-9 segmented). Eyes oval, on a small basal cone. Labium 3-segmented, longer than wide. Posterior pair of spiracles always larger than anterior spiracles. Circulus present or absent, lying between abdominal segments III and IV. Legs well-developed, claw with or without a denticle; tarsal digitules hair-like, not capitate; claw digitules knobbed, claw digitules broader than tarsal digitules. Both pairs of ostioles well-developed; anterior ostioles usually more weakly developed than posterior pair. Anal lobes poorly developed. Anal ring oval, with 1 inner row of pores and one or two outer rows of pores plus with 6 setae. Discodial pores present in different of sizes, scattered through.

\section{Dorsum.}

Cerarii present only on posterior abdominal segments (rarely $\mathrm{C}_{3}$ present). Dorsal body setae flagellate but strong and various sizes. Multilocular disc pores present or absent (generally absent). Quinquelocular pores generally absent (present only in $F$. stepposa). Oral collar tubular present of absent, if present in transverse rows on body segments. Trilocular pores each 3-5 $\mu \mathrm{m}$ in diameter, often slightly larger than ventral trilocular pores; scattered over dorsum. Minute discoidal pores present, from a few to scattered on the surface, different in sizes.

Venter. Most ventral setae slender and hair-like, of various sizes. Oral collar tubular ducts of one or two sizes, each varying in length and width. Multilocular disc pores present on posterior abdominal segments, especially around vulva. Quinquelocular pores either absent, present medially on thorax or scattered throughout. Trilocular pores, each 2.5-5.0 $\mu \mathrm{m}$ in diameter, scattered throughout. Discoidal pores of different sizes, scattered through. 
Key to adult female Fonscolombia (modified from Danzig, 2007).

1- Circulus absent 2

- Circulus present, sometimes 2 rarely 3 in number .................................................. 5

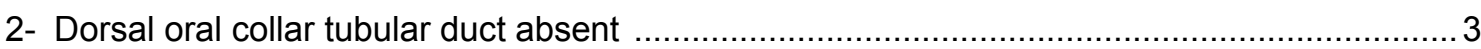

- Dorsal oral collar tubular duct present ..................................................................... 4

3- Antannae 6 segmented; coxa and femur with translucent pores

F. europaea (Newstead)

- Antannae 7 segmented; coxa and femur without translucent pores

F. tshadaevae (Danzig)

4- Multilocular disc pores present on last 5 posterior abdominal segments; dorsal oral collar tubular ducts scattered through dorsum F. graminis Lichtenstein

- Multilocular disc pores present on only last 2 posterior abdominal segments; dorsal oral collar tubular ducts present only on posterior abdominal segments on dorsum

F. butorinae Gavrilov \& Danzig

5- Circuli convex, sclerotized, 1-3 in number 6

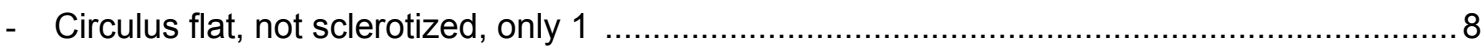

6- Circuli 2 rarely 3 in number, claw with distinct denticle 7

- Circulus 1, claw without distinct denticle F. edentata (Danzig)

7- Quinquelocular pores on dorsum present F. stepposa (Mathesova)

- Quinquelocular pores on dorsum absent F. tomlinii (Newstead)

8- Dorsal oral collar tubular ducts present; translucent pores on femur and tibia absent..... 9

- Dorsal oral collar tubular ducts absent; translucent pores on femur and tibia present

F. ulusoyi sp.n.

9- Oral collar tubular duct not arranged in groups along margin of abdominal segments; quinquelocular pores absent on venter

- Oral collar tubular duct arranged in groups along margin of abdominal segments; quinquelocular pores numerous on venter

F. herbacea (Danzig)

10- Anal lobe cerarii with 8-12 enlarged conical setae; oral collar tubular ducts on dorsum numerous

F. amnicola (Borchsenius)

- Anal lobe cerarii with 2-3 enlarged conical setae; oral collar tubular ducts on dorsum few

F. stipae (Nurmamatov)

Fonscolombia ulusoyi sp. n. (Fig. 1).

Material studied. Holotype female, Turkey, Iğdır-Tuzluca-Gaziler, N: 4006'218”; E: 04327'952”; 1000 m; on Stipa sp. (Poaceae), 29.v.2008, coll: M. Bora Kaydan, (KPCT: 4367); Paratypes. 2 females with same data with Holotype; 1 female, Turkey, Erzurum-Horasan-Köprüköy road, N: 3957'252"; E:042 $17^{\prime} 166^{\prime \prime} ; 1690$ m; on Festuca sp. (Poaceae), 09.07.2010, coll: M. Bora Kaydan (KPCT:4827). 


\section{Description.}

Adult female. Body elongate oval, $1.34-1.68 \mathrm{~mm}$ long, 0.83-1.37 mm wide. Eye marginal, 35-40 $\mu \mathrm{m}$ wide. Antenna 6 segmented, 260-280 $\mu \mathrm{m}$ long; apical segment 75-80 $\mu \mathrm{m}$ long, 25-30 $\mu \mathrm{m}$ wide, with apical setae 22.5-27.5 $\mu \mathrm{m}$ long plus three fleshy setae, each 20-35 $\mu \mathrm{m}$ long. Tentorium 180-210 $\mu \mathrm{m}$

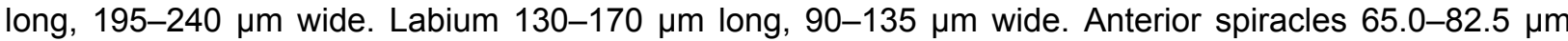
long, 32.5-42.5 $\mu \mathrm{m}$ wide across atrium; posterior spiracles 75-90 $\mu \mathrm{m}$ long, 37.5-55.0 $\mu \mathrm{m}$ wide across atrium. Circulus oval, between abdominal segments III and IV, 55-100 $\mu \mathrm{m}$ wide. Legs well developed; data for posterior legs: coxa 102.5-130 $\mu \mathrm{m}$, trochanter + femur 165-190 $\mu \mathrm{m}$, tibia + tarsus 175-200 $\mu \mathrm{m}$, claw 20-30 $\mu \mathrm{m}$. Ratio of lengths of tibia + tarsus to trochanter + femur 1.02-1.70:1; ratio of lengths of tibia to tarsus 1.23-1.70:1; ratio of length of hind trochanter + femur to greatest width of femur 3.453.80:1. Tarsal digitules each $15 \mu \mathrm{m}$ long, hair-like. Claw digitules knobbed each 17.5-22.5 $\mu \mathrm{m}$ long. Hind tibia with 20-25 translucent pores. Anterior ostioles each with a total for both lips of 15-29 trilocular pores and 4-7 setae; posterior ostioles each with a total for both lips of 28-46 trilocular pores and 4-9 setae. Anal ring 62.5-80.0 $\mu \mathrm{m}$ wide, with 6 setae, each seta $45-85 \mu \mathrm{m}$ long. Cerarii 2 pairs only, each slightly sclerotized; anal lobe cerarii each with 4 or 5 slender enlarged setae, 17.5-22.5 $\mu \mathrm{m}$ long, plus 14-24 trilocular pores and 2 or 3 spine-like auxiliary setae; cerarius on abdominal segment VII with 2 slender enlarged setae and 4-6 trilocular pores.

Dorsum. Body setae flagellate but strong and various sizes, each 7.5-12.5 $\mu \mathrm{m}$ long. Oral collar tubular ducts absent. Trilocular pores, each 2.5-3.0 $\mu \mathrm{m}$ in diameter, scattered over entire body. Minute discoidal pores scattered through, each $4-5 \mu \mathrm{m}$ in diameter.

Venter. Setae slender hair-like setae, each 7.5-22.5 $\mu \mathrm{m}$ long, longest setae medially on head just above tentorium in one pair. Apical setae of anal lobe each 120-160 $\mu \mathrm{m}$ long. Multilocular disc pores in rows on abdominal segments: V 0-2, VI 10-16, VII 36-39, VIII + IX 24-27; each pore 8-10 $\mu \mathrm{m}$ in diameter. Quinquelocular pores absent. Trilocular pores, each 2.5-3.0 $\mu \mathrm{m}$ in diameter, scattered throughout. Minute discoidal pores few, each 4-5 $\mu \mathrm{m}$ in diameter, scattered throughout. Oral collar tubular ducts concentrated on body margin and in single rows across all abdominal segments, of various (generally 2 sizes visible) sizes, each 8-10 $\mu \mathrm{m}$ long, 2.5-4 $\mu \mathrm{m}$ wide, on mid thorax and abdominal segments: II-III 59-82 ducts, IV 44-66, V 54-57, VI 35-49, VII 12-27, VIII + IX 22-25.

Comments. Fonscolombia ulusoyi spec. n. can be readily distinguished in having: (i) two cerarii on the posterior abdominal segments; (ii) absence of oral collar tubular ducts on dorsum; (iii) absence of quinquelocular pores on venter; (iv) large discoidal pores on both on venter and dorsum and (v) circuli present. However $F$. ulusoyi is closest to $F$. herbaceae in having large discoidal pores and circulus on venter but differs in lacking oral collar tubular ducts on dorsum and lacking quinquelocular pores on venter. Fonscolombia ulusoyi is also similar to $F$. europaea in lacking oral collar tubular ducts on the dorsum but different from this species in having a circulus on venter. Fonscolombia ulusoyi is also close to F. stipae in lacking oral collar tubular duct on the dorsum and in having a circulus on venter but differs in having 6 segmented antennae (7 segmented antennae in F. stipae) and only two cerarii on abdominal segments (6 pairs of cerarii in F. stipae).

Etymology. This species is named after Prof. Dr. M. Rifat ULUSOY, who contributed to the studies of whitefly (Hemiptera: Aleyrodoidea ) fauna in Turkey.

Host plants. On Stipa sp. and Festuca sp. (Poaceae).

Distribution. Turkey. 


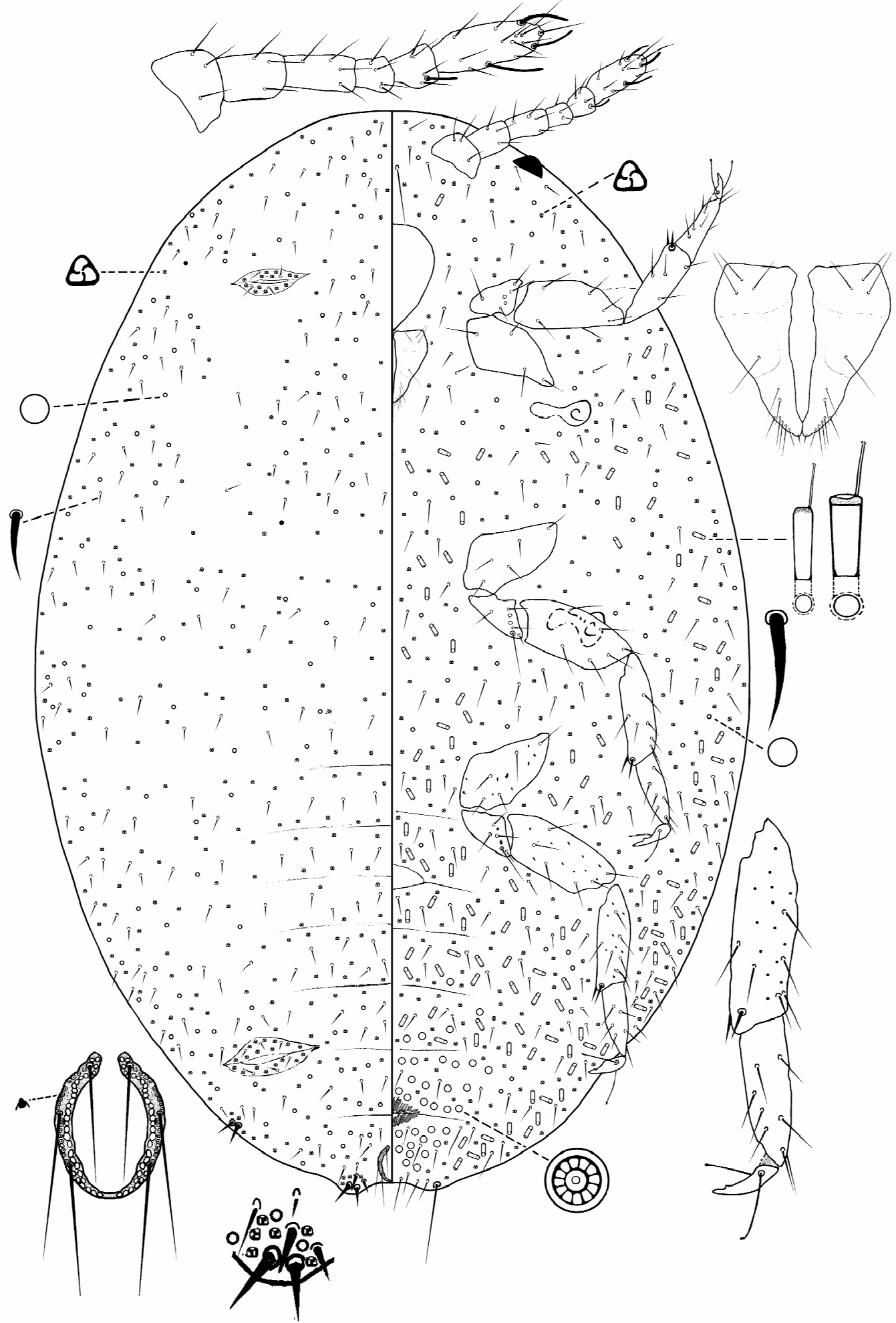

Figure 1. Fonscolombia ulusoyi sp. nov., holotype. 


\section{Acknowledgements}

I would like to thank the TUBITAK TOVAG (104 O 148 and 108 O 325) for financial support of this project. Special thanks to Dr. Malkie Spodek (Department of Entomology, Agricultural Research Organization The Volcani Center, Bet Dagan, 50250 Israel) for reviewing the manuscript.

\section{References}

Ben-Dov, Y. \& D. Matile-Ferrero, 1989. Taxonomy and nomenclature of five hitherto inadequately-known genera of mealybugs (Homoptera: Coccoidea: Pseudococcidae). Systematic Entomology 14: 165178.

Ben-Dov, Y., D. R. Miller \& G. A. P. Gibson, 2014. ScaleNet: A Database of the Scale Insects of the World. (Web page: http://www.sel.barc.usda.gov/SCALENET/ SCALENET.HTM.) (Date accessed: July 2014)

Borchsenius, N.S. 1948. Toward a revision of the genus Phenacoccus Ckll. (Insecta, Homoptera, Coccoidea). (In Russian). Doklady Akademii Nauk SSSR. Moscow (n.s.) 61: 953-956.

Danzig, E.M. 1994. Zur subalpinen und alpinen Schildlausfauna (Homoptera, Coccinea) der Schweizer Alpen Mitteilungen der Schweizerischen Entomologischen Gesellschaft/Bulletin of the Societe Entomologique Suisse 44(2): 45-48.

Danzig, E.M. 2007. Mealybugs of the Genus Fonscolombia Licht. (Homoptera, Pseudococcidae) of the Fauna of Russia and Adjacent Countries (In Russian with English Summary). Entomologicheskoe Obozrenye 86 (2): 363-377.

Goux, L. 1994. Étude d'une cochenille nouvelle de la région lyonnaise, avec définition d'un genre nouveau (Homoptera, Coccoidea, Pseudococcidae). Bulletin de la Société Linnéenne de Provence 45: 41-43.

ICZN, 1991. Opinion 1654. Fonscolombia Lichtenstein, 1877 (Insecta, Homoptera): Fonscolombia graminis Lichtenstein, 1877 Fixed as the Type Species," Bull. Zool. Nomenclat. 48 (3), 266-267.

Kaydan M. B., S. Ülgentürk \& L. Erkılıç, 2013. Checklist of Turkish Coccoidea (Hemiptera: Sternorryncha) species. Turkish Bulletin of Entomology, 3 (4): 157-182.

Kosztarab, M. \& F. Kozár, 1988. Scale Insects of Central Europe. Akademiai Kiado, Budapest, Hungary, and Dr W. Junk Publishers, Dordrecht, The Netherlands, $456 \mathrm{pp}$.

Kozár, F. 1998. "Pseudococcidae. 452" In: Catalogue of Palaearctic Coccoidea (Ed. F. Kozár). Plant Protection Institute, Hungarian Academy of Sciences, Budapest, Hungary. 526 pp.

Lichtenstein, J. 1877. Mr Lichtenstein responds to the following note: M. J. Lichtenstein addresse la note qui suit: Bulletin entomologique 12: cviii-cix.

Matile-Ferrero, D. 2004. Taxonomie nomenclature et répartition en France de trois espèces du genre Fonscolombia Lichtenstein, 1877, (Hemiptera, Pseudococcidae). Revue Française d'Entomologie 26(2): 73-76.

Williams, D.J. 2004. Mealybugs of Southern Asia. The Natural History Museum, Kuala Lumpur: Southdene SDN. BHD. 896 pp. 
